\title{
New molecular markers for revealing the population structure of Chthamalus stellatus in the Mediterranean and the eastern Atlantic
}

\author{
Naama Sasson, Noa Simon-Blecher, Yair Achituv* \\ The Mina and Everard Goodman Faculty of Life Sciences, Bar Ilan University, Ramat Gan 52900, Israel
}

\begin{abstract}
This study addressed the hypothesis that the lack of genetic variation among populations of the barnacle Chthamalus stellatus, detected in previous phylogeographic studies, is due to the limitations of the selected markers. We developed novel markers for this species based on 2 mitochondrial sequences, i.e. a 640 bp fragment of NADH dehydrogenase subunit 2 (ND-2) and a $228 \mathrm{bp}$ fragment of the control region (CR). We found that ND-2 is highly conserved in the chthamalids and thus is not suitable for phylogenetic analyses of this group. In the CR, 204 haplotypes were recognized, of which 182 were singletons. The range of pairwise differences between populations was 6.7 to 8.9 . The high variance ( 85 to $89 \%$ ) of the CR occurs within populations, leaving only 11 to $15 \%$ of the variation between populations. The model separating the Azores population from the other Atlantic populations, and the Mediterranean population from the Atlantic populations, gave the highest variation among groups. But due to the limitations of the markers used, the hypothesis that there is genetic variation among populations of C. stellatus needs further support. The low variability of the ND-2 gene and the high variability of the CR limit the validity separation of populations of C. stellatus. The phylogeographical study of chthamalids requires development of different genetic markers; it is possible that the use of microsatellites could fulfill these requirements and reveal significant differences among populations.
\end{abstract}

KEY WORDS: Molecular markers - ND-2 - Control region · Distribution - Mediterranean - East Atlantic $\cdot$ Chthamalus stellatus

Resale or republication not permitted without written consent of the publisher

\section{INTRODUCTION}

The 2 chthamalid barnacle species Chthamalus stellatus and C. montagui are widespread in the intertidal zone of the Mediterranean and the eastern Atlantic. The known distribution range of $C$. stellatus and C. montagui was summarized by Crisp et al. (1981), but their detailed study was restricted to the distribution of the population in the British Isles. Subsequently, the most comprehensive distribution of these species in the northeast Atlantic, the Mediterranean, and the Black Sea was presented by Pannacciulli et al. (1997). Dando et al. (1979) compared the differences among populations of $C$. stellatus and $C$. montagui from the Adriatic and southwest England and found that C. montagui from the Adriatic differed from the English population, whereas C. stellatus from all sites had similar allele frequencies. Slight variations in the allozyme frequencies of the glutamate oxaloacetate transaminase (GOT) locus of $C$. stellatus were later reported (Pannacciulli et al. 1997), suggesting genetic differences between the Atlantic and the Mediterranean populations. Indeed, that study suggested that the observed absence of higher genetic variability between C. stellatus populations, based on variations of allozyme frequencies, might be due to the limitations of this marker. These findings led to the use of mitochondrial DNA (mtDNA) and nuclear DNA markers to confirm the genetic differences of populations of $C$. montagui and C. stellatus 
(Shemesh et al. 2009). Based on previous studies, these authors selected the mitochondrial gene cyto chrome oxidase subunit I (COI), which was previously successfully used for separation of barnacle populations (van Syoc 1994, 1995, Puspasari et al. 2001, Sotka et al. 2004, Campo et al. 2009) including Chthamalus (Wares 2001, Tsang et al. 2008). Another 2 genes used by the latter 2 authors are the nucleic gene elongation factor- $1 \alpha(E F-1 \alpha)$, which was used by Sotka et al. (2004) to show differences in populations of Balanus glandula along the northeastern Pacific Ocean, and a genetic region that encompasses the internal transcribed spacer 1 (ITS 1), 5.8S rDNA and ITS 2 (ITS). Chan et al. (2007) used ITS as a marker to study the population genetics of Tetraclita spp. Shemesh et al. (2009) found that while the EF-1 sequences of $C$. stellatus isolated the Atlantic population from the Mediterranean and Aegean ones, the COI and ITS data sets, surprisingly, did not show significant population structure for this species and could not confirm the results of Pannacciulli et al. (1997); the discrepancy may reflect a limitation of these markers.

The present study was designed to support the assumption that there is genetic variation among populations of Chthamalus stellatus and that the lack of phylogeographic differences is indeed due to the limitation of the markers. To this end, we developed novel markers with higher intraspecific variability. Sorenson et al. (1999) noted that the traditional gene for population study, cytochrome oxidase, had been sequenced more often than other genes, due to the early availability of universal primers. However, they suggested that the historical inertia should be replaced by a choice of genes that are likely to be the most informative for a given study. Arif \& Khan (2009) stated that protein-coding genes should be used in low categories such as families, genera, and species but not in population studies. Calderón et al. (2006) used COI and ITS to analyze the genetic structure of Mediterranean gorgonians. Both markers failed to make evident any genetic structure of these populations. It seems that COI markers may be useful for population level studies in some cases, but not in C. stellatus. We selected the 2 mitochondrial genes, NADH dehydrogenase subunit 2 (ND-2) and the control region $(\mathrm{CR})$, also known as the 'D-loop region', or 'A+T-rich region of mtDNA,' as potential markers for separation of intraspecific populations with high resolution.

ND-2 was previously used to infer intraspecific variation mainly in vertebrates, although reports of its use in invertebrates are rare. ND-2 together with $\mathrm{COI}$, in conjunction with morphological and ecologi- cal data, were used to elucidate the taxonomy of morphotypes of the crinoid Phanogenia gracili (Owen et al. 2009).

The CR is the most variable segment of the mtDNA and is characterized by high evolutionary dynamics and variability (Wilson et al. 1985, Williams et al. 1990, Shadel \& Clyton 1997). Its evolutionary rate is higher by 3 - to 5 -fold relative to other parts of the mitochondrial genome (Brown et al. 1993). The high level of intraspecific genetic variability favors its use in phylogeographical and population genetic studies of a variety of organisms. The CR is the largest noncoding segment of the mitochondrial genome and contains most of the regulatory elements for duplication and expression of the mtDNA (Pie et al. 2008). However, most of the studies using the $\mathrm{CR}$ as a marker involved vertebrates and insects. In cirripedes, Tsang et al. (2007) used the CR sequences to elucidate the taxonomic position of the 2 East Asian species of Tetraclita, T. japonica and T. formosana. Based on their analyses, they concluded that these are not distinct species, but subspecies of $T$. japonica. York et al. (2008) used the 2 mitochondrial genes (COI and CR) and microsatellites to study the phylogeography of Catomerus polymerus in southern Australia. The mitochondrial data showed high levels of genetic divergence between an eastern and a western clade. Divergence among the 2 clades was high, $3.5 \pm 0.76 \%$, for COI, and even higher, $6.7 \pm 0.65 \%$, for the CR. The deep phylogeographic split indicated allopatric divergence related to the emergence of the Bass Strait, between Australia and Tasmania, during glacial periods. The contemporary structure of $C$. polymerus populations is maintained by the current system around southern Australia. These findings indicate the potential utility of $\mathrm{CR}$ in interpretation of divergence in cirripede populations.

One of the disadvantages of the use of these markers is the lack of 'universal' primers, and that there are no large conserved regions in the CR of Tetraclita and of Catomerus polymerus or any similarity at the nucleotide level among these taxa. The complete mitochondrial sequence is known in 4 species of cirripedes, Megabalanus volcano (GenBank accession number NC006293) Tetraclita japonica (NC008974), Pollicipes polymerus (AY456188), and P. mitella (AY514042). In these cirripedes, the ND-2 is located next to the CR, and both genes are flanked by the genes encoding 12S rRNA and COI. In the present study, the DNA sequence of the region containing ND-2 and CR was determined, and primers developed on the basis of this sequence were used to investigate the phylogeography of Chthamalus stellatus. 


\section{MATERIALS AND METHODS}

\section{Samples}

The collection of specimens from Shemesh et al. (2009) was used as the source of material for the present study. In a few cases, we used DNA already extracted by Shemesh et al. (2009) and maintained at Bar Ilan University. Additional DNA was extracted as described by Shemesh et al. (2009). For detection and amplification of the segment that contained the ND-2 gene and the $\mathrm{CR}$, material from Michmoret-Dor, Israel, was used. For amplification of the ND-2 fragment, samples were selected from 15 populations (Fig. 1); for the CR amplification, 6 populations of Chthamalus stellatus were selected, from different parts of its range of distribution, depending on the availability of sufficient material. These populations include those from Michmoret-Dor, Israel $\left(36^{\circ} 36^{\prime} \mathrm{N}\right.$, $\left.34^{\circ} 55^{\prime} \mathrm{E}\right)$, representing the eastern distribution range, from St Jean Cap Ferrat, France $\left(43^{\circ} 41^{\prime} \mathrm{N}, 7^{\circ}\right.$ $\left.19^{\prime} \mathrm{E}\right)$, in the western Mediterranean; Cork, Ireland $\left(51^{\circ} 53^{\prime} \mathrm{N}, 8^{\circ} 28^{\prime} \mathrm{W}\right)$ from the eastern Atlantic; and 3 island populations from the eastern Atlantic islands,

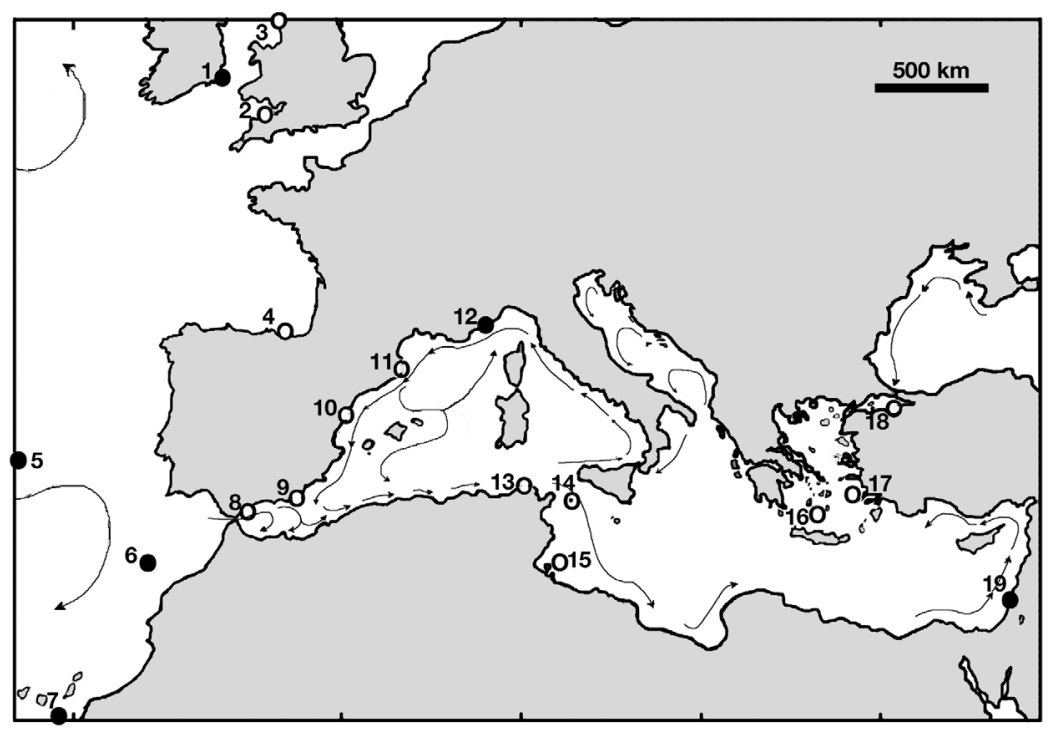

Fig. 1. Northeastern Atlantic Ocean and Mediterranean Sea. Numbers indicate individual collection sites, but when 2 collection sites are very close they are indicated by a single number. 1: Cork, Ireland; 2: Plymouth, England; 3: Seil Island and Loch Sween, Scotland; 4: Gijon, Spain; 5: Azores, Portugal; 6: Madeira, Portugal; 7: Tenerife, Spain; 8: Gibraltar, Gibraltar; 9: Malaga, Spain; 10: Valencia, Spain; 11: Banyuls sur Mer, France; 12: St Jean Cap Ferrat, France; 13: Bizerte, Tunisia; 14: Pantelaria Island, Italy; 15: Jerba, Tunisia; 16: Koufonisi, Greece; 17: Turgutreis, Turkey; 18: Buyuk Ada, Turkey; 19: Dor-Michmoret, Israel. (O) Samples used for ND-2 amplification; () samples used for control region amplification; samples from Localities 1 and 19 were used for amplification of both genes. Main currents indicated are adapted from Millot \& Taupier-Letage (2005) and Sy (1988) i.e. the Azores $\left(38^{\circ} 30^{\prime} \mathrm{N}, 28^{\circ} 0^{\prime} \mathrm{W}\right)$, Madeira $\left(32^{\circ} 46^{\prime}\right.$ $\left.\mathrm{N}, 17^{\circ} 0^{\prime} \mathrm{W}\right)$, and Tenerife $\left(28^{\circ} 16^{\prime} \mathrm{N}, 16^{\circ} 36^{\prime} \mathrm{W}\right)$ in the Canary Islands. About 50 specimens from each locality were analyzed.

\section{Selection of outgroup}

Two species of Octomeris, O. brunnea, and O. angulosa, were selected as the outgroup. The 8-plated ructure of these species is a plesiomorphic characistic, and the reduction in the number of plates by tera, as found in Chthamalus, is regarded as an

DNA was extracted from the ethanol-preserved (P) polymerase chain reac(Sigma-Aldrich) was used for amplification by PCR (Saiki et al. 1988) with 50 ng DNA per reaction. PCR, inverse $\mathrm{PCR}$, and chromosome walking were used to identify the mtDNA fragments that contain the sequences of the CR and the ND-2. We used a modification of the procedure described by Ochman et al. (1988). The procedure for revealing the fragment of mtDNA that contains the markers of interest and the primers used is presented in Appendix 1.

For amplification of ND-2 and the $\mathrm{CR}$, we used nested PCR. Primers were designed based on the segment of the mitochondrial genome of Chthamalus stellatus amplified by us at the first stage of the present study. Forward and reverse primers for the first amplification of CR are forward: CRL1- 5'CAG TTC TAT GGT TTC TGC TGT AGA GTA CCT-3', reverse: INnR1- 5'GCA GCC TCT CTT CTC TTT TTG TTG TTT TCC-3'. For the second amplification, primers were forward: CRL2- 5'-GTT CCT GAT TGA CTC TAA GTA TGT CT-3', reverse: INnR35'-AGT GTA ACC ACT ATC GTT GGG G-3. This set of primers was tested in other species of Chthamalus, but it was found to be specific to C. stella- 
tus. For amplification of the ND-2, semi-nested PCR was used. The forward primer of the first reaction was IntF2- 5'-TTG AGA ACT AAA TTG GGA ATG GCT CC-3'; for the second, nested, reaction, the forward primer was IntF2- 5' - TGA TTT CCT GAG GTA ATT GAA GGC-3'. The same reverse primer was used for both PCR reactions: t-trp-RR 5'-TTA CGG CTT TGA AGG CCA TCA G-3'. These primers were also used for amplification of ND-2 of other chthamalids.

All PCR started with a denaturation step of 3 min at $94^{\circ} \mathrm{C}$. The first stage amplification of CR was performed by 35 cycles of $30 \mathrm{~s}$ at $94^{\circ} \mathrm{C}, 30 \mathrm{~s}$ at $57^{\circ} \mathrm{C}$, and $40 \mathrm{~s}$ at $72^{\circ} \mathrm{C}$, followed by a final extension of $6 \mathrm{~min}$ at $72^{\circ} \mathrm{C}$. The second, nested, reaction was amplified by 25 cycles of $30 \mathrm{~s}$ at $94^{\circ} \mathrm{C}, 30 \mathrm{~s}$ at $52^{\circ} \mathrm{C}$, and $30 \mathrm{~s}$ at $72^{\circ} \mathrm{C}$, followed by a final extension of $6 \mathrm{~min}$ at $72^{\circ} \mathrm{C}$. Amplification was carried out in a personal combithermocycler (Biometra). The ND-2 was amplified by performing 35 cycles of $30 \mathrm{~s}$ at $94^{\circ} \mathrm{C}, 30 \mathrm{~s}$ at $55^{\circ} \mathrm{C}$ and $1 \mathrm{~min}$ at $72^{\circ} \mathrm{C}$, followed by a final extension of $7 \mathrm{~min}$ at $72^{\circ} \mathrm{C}$. The second (nested) reaction was amplified by 25 cycles of $30 \mathrm{~s}$ at $94^{\circ} \mathrm{C}, 30 \mathrm{~s}$ at $53^{\circ} \mathrm{C}$, and $50 \mathrm{~s}$ at $72^{\circ} \mathrm{C}$, followed by a final extension of $6 \mathrm{~min}$ at $72^{\circ} \mathrm{C}$.

PCR products were purified using the High Pure PCR product purification kit (Roche Diagnostics). PCR products were sequenced on both strands using an ABI PRISM 3100 Genetic Analyzer (Applied Biosystems) at Tel Aviv University or by Macrogene Inc., Seoul (Korea). All sequences were deposited in GenBank. Sequences were aligned using MAFFT v6 in the G-INS-i mode (Katoh et al. 2005) and truncated to the same length using Gblocks v0.91b (Castresana 2000).

To define the haplotypes of sequences, COLLAPSE software was employed (http://darwin.uvigo.es/software/collapse.html), which collapses the aligned sequences to haplotypes and indicates which sequences belong to which haplotype. Analyses of molecular variance (AMOVA) between the aligned sequences of the 6 populations were conducted using ARLEQUIN software (http://cmpg.unibe.ch/ software/arlequin3; Excoffier et al. 2005). Finally, Tajima's D-test (Tajima 1989) embedded in Arlequin was used to test the departures from mutation-drift equilibrium within each population.

\section{RESULTS}

Using chromosome walking and inverse PCR, we amplified 2 contiguous fragments of the mtDNA of Chthamalus stellatus, one composed of $121 \mathrm{bp}$ of the large ribosomal RNA(rRNA) (16SrRNA), 70 bp of tRNA of valine, and $664 \mathrm{bp}$ of the small rRNA (12S rRNA).
There is a gap between this section and the second section, which contains 322 bps of the $C R$, transfer RNA(tRNA) of methionine, the entire ND-2 gene (999 bps in length), tRNA of tryptophan and $708 \mathrm{bp}$ of the COI gene. These contigs were deposited in GenBank under accession numbers JN989652 and JN989956.

\section{ND-2 marker}

The sequences of Chthamalus stellatus are deposited in GenBank under accession numbers JN989657 and JN989673-JN989687. The aligned ND-2 data set of C. stellatus includes fragments of $640 \mathrm{bp}$, from 15 populations covering most of the distribution range of this species (Fig. 1). The aligned sequences included 602 invariable positions, 38 variable positions of which only 14 were phylogenetically informative. Phylogenetic analysis yielded a tree (not presented) with low substitution rate values with no bootstrap support for any branch except one (including the samples from Pantelleria, Gijon, and Plymouth). The resulting tree had no phylogeographic meaning. Adding sequences of other species of Chthamalus and other chthamalids (GenBank accession numbers JN989653JN989656 and JN989658-JN989672) increased the number of variable sites to 69, of which 25 were informative but did not reveal clear separation of genera and species. Furthermore, these additional sequences blurred the picture by clustering species of different genera, and placing species of the same genus on different branches of the phylogenetic tree; thus, bootstrap support of branches was very low. We conclude that ND-2 is highly conserved in the chthamalids and is not a suitable marker for phylogenetic analyses of this group.

\section{Control region}

The CR sequence data was based on 268 sequences from the 6 populations (GenBank accession numbers JN989688-JN989955). The aligned sequence is 228 bp long, of which 145 are variable. The neighbor-joining (NJ) tree (Fig. 2) did not reveal a phylogeographic pattern, COLLAPSE of the edited data set recognized 204 haplotypes (http://darwin.uvigo.es/software/collapse .html), and the most abundant haplotype was represented by 12 specimens; 182 haplotypes were singletons, represented in our samples by only 1 specimen.

Tamura and Nei pairwise genetic distance analyses results (Table 1) indicate that there was no significant difference between $F_{\mathrm{ST}}$ values of the population of the 
3 Atlantic island groups. The difference between the population of St Jean Cap Ferrat in the western Mediterranean and that of Cork in Ireland is significant but small. The population of Dor (Israel) was isolated from all other populations. Population average pairwise differences showed the same pattern (Table 1). Pairwise differences within the populations were high, and those of the Azores were higher than those found within other populations. Differences within the Dor population were the smallest.

Five alternative models were tested by clustering the populations using Arlequin, presenting different groupings of the populations (Table 2). The within-population differences contributed about 85 to $89 \%$ of the variation. The different grouping contributed only a small part of the variation, but significance tests support all of the groupings. Separation of Cork from the other Atlantic populations (Models 1 and 4) gave the highest variation among the groups and nearly obliterated the variation among the groups, reflecting the strong signal provided by the population of Cork and revealing its diver-

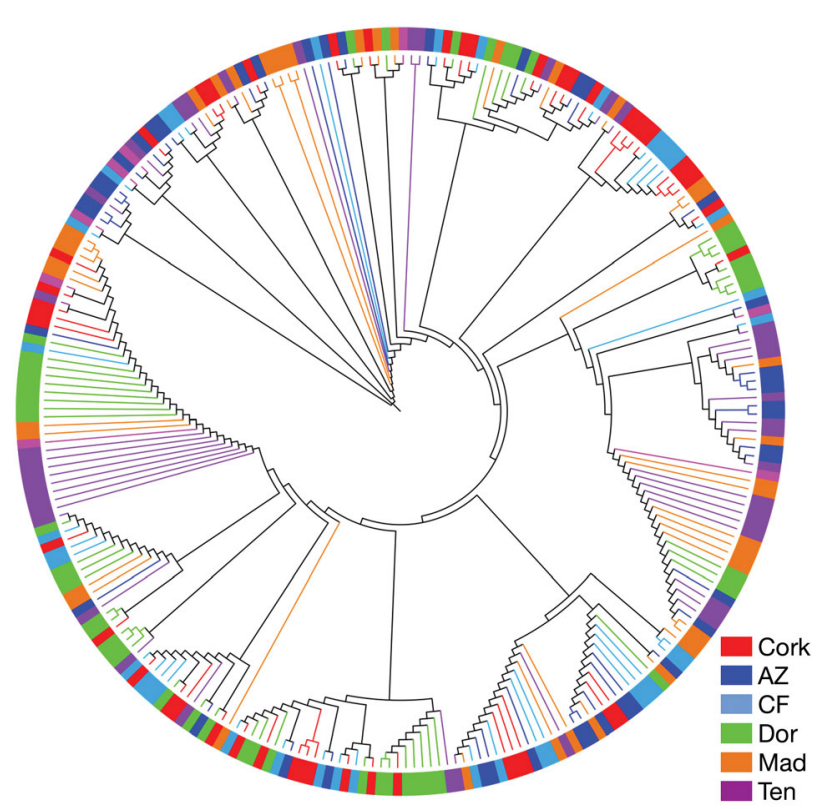

Fig. 2. Neighbor-joining tree based on the control region marker. Cork: Cork, Ireland; AZ: Azores, Portugal; Mad: Madeira, Portugal, Ten: Tenerife, Spain; CF: St Jean Cap Ferrat, France; Dor: Dor-Michmoret, Israel
Table 1. Chthamalus stellatus. Diagonal (in italics) shows average number of pairwise differences within populations. Above diagonal: Tamura and Nei population pairwise genetic distances based on the control region sequences $\left(F_{\mathrm{ST}}\right)$. Below diagonal: average number of pairwise differences between populations. Bold type indicates no significant difference

\begin{tabular}{|lcccccc|}
\hline & Cork & Azores & Madeira & Tenerife Cap Ferrat & Dor \\
\hline Cork & 7.0483 & 0.0614 & 0.0701 & 0.0745 & 0.0348 & 0.1178 \\
Azores & 7.9386 & 7.8574 & $\mathbf{0 . 0 0 5 5}$ & 0.0250 & 0.0907 & 0.2107 \\
Madeira & 7.3303 & 7.2595 & 6.5870 & $\mathbf{0 . 0 0 0 3}$ & 0.1118 & 0.2034 \\
Tenerife & 7.4659 & 7.5006 & $\mathbf{6 . 6 8 0 0}$ & 6.7698 & 0.1232 & 0.1860 \\
Cap Ferrat & 7.1476 & 8.0355 & 7.5035 & 7.7082 & 6.7468 & 0.0626 \\
Dor & 7.5876 & 8.9752 & 8.1167 & 8.0506 & 6.9791 & 6.3441 \\
\hline
\end{tabular}

Table 2. Chthamalus stellatus. Variations in mitochondrial control region haplotypes in populations clustered into 5 different groupings of populations and subject to analysis of molecular variance. Each group is designated by square brackets. See Fig. 2 for full location names. Significance levels: ${ }^{*} p>0.1$; ${ }^{* *} \mathrm{p}=0.05-0.1{ }^{* * *} \mathrm{p}<0.05$

\begin{tabular}{|lcccc|}
\hline $\begin{array}{l}\text { Model } \\
\text { number }\end{array}$ & $\begin{array}{c}\text { Within } \\
\text { populations }\end{array}$ & $\begin{array}{c}\text { Among } \\
\text { populations } \\
\text { within group }\end{array}$ & $\begin{array}{c}\text { Among } \\
\text { groups }\end{array}$ & Grouping model \\
\hline 1 & $88.16^{*}$ & $0.95^{*}$ & $10.89^{* *}$ & $\begin{array}{c}\text { [Cork]-[AZ;Mad;Ten]- } \\
{[\mathrm{CF}]-[\mathrm{Dor}]}\end{array}$ \\
2 & $86.60^{*}$ & $3.80^{* * *}$ & $9.61^{* *}$ & $\begin{array}{c}\text { [Cork;AZ;Mad;Ten]- } \\
{[\mathrm{CF}]-[\mathrm{Dor}]}\end{array}$ \\
4 & $85.92^{*}$ & $4.14^{* * *}$ & $9.94^{* *}$ & $\begin{array}{c}\text { [Cork; AZ; Mad; Ten]- } \\
{[\mathrm{CF} ; \text { Dor] }} \\
{[\mathrm{Cork}]-[\mathrm{AZ}]-[M a d ; T e n]-} \\
{[\mathrm{CF}]-[\mathrm{Dor}]}\end{array}$ \\
5 & $89.47^{*}$ & $-0.03^{*}$ & $10.56^{* *}$ & $\begin{array}{c}\text { [AZ]-[Cork; Mad; Ten]- } \\
\text { [CF]-[Dor] }\end{array}$ \\
\hline
\end{tabular}

gence from the other populations. The analyses of among-groups and among populations-within group are based on about 11 to $15 \%$ of the variation.

Results of Tajima's $D$-test performed on each population are given in Table 3. All species presented moderately negative $D$ values, although only the population of Dor was significant. The Tajima $D$-test revealed no departure from mutation-drift equilibrium, and the mismatch analyses of pairwise differences were characteristic of populations with constant size over time.

Table 3. Chthamalus stellatus. Tajima's neutrality test ( $D$-test) and test of goodness of fit to the model's sudden expansion, for each population

\begin{tabular}{|lccc|}
\hline Population & Sample size (n) & Tajima's $D$ & $\mathrm{p}$ \\
\hline Cork & 46 & -1.3859 & 0.0640 \\
Azores & 42 & -1.0636 & 0.1330 \\
Madeira & 50 & -0.9891 & 0.1620 \\
Tenerife & 43 & -0.7324 & 0.2440 \\
Cap Ferrat & 37 & -1.0716 & 0.1370 \\
Dor & 50 & -2.1143 & 0.0020 \\
\hline
\end{tabular}




\section{DISCUSSION}

\section{ND-2 data set}

This gene was found to be inadequate for separation of taxa of chthamalids. The ND-2 of chthamalids was not informative due to the high similarity of the nucleotide sequence of various isolates. The identity within the chthamalids ranges between 97 and $99 \%$. However, this is not the case with all cirripedes. The identity among the 3 species of Pollicipes, P. mitella (AY514042) P. polymerus (NC 005936), and P. pollicipes (AY456188), is low and is $69 \%$ between $P$. pollicipes and $P$. mitella, $70 \%$ between $P$. polymerus and $P$. mitella, and $75 \%$ between $P$. pollicipes and $P$. polymerus.

This is in contrast to the situation in COI sequences, for which Fisher et al. (2004) showed that in the chthamalids, at intergeneric levels, COI was saturated with substitutions beyond phylogenetic information, and phylogenetic trees of chthamalids based on COI were meaningless. However, the vast majority of these substitutions were conservative, occurring at the third position within the codon and did not affect the amino acid sequence of the encoded protein. Thus, the utility of using the 2 protein-encoding mitochondrial genes, ND-2 and COI, to study the phylogeny of chthamalids is poor, the former because of its low variability and the latter because of its high variability. The available data on ND-2 variability in higher taxonomic units indicate that this gene might be suitable for analysis of taxa at this level.

\section{CR data set}

As expected, the CR is very variable, and more than half of the haplotypes are singletons. $F_{\mathrm{ST}}$ values using Tamura and Nei pairwise genetic distance analyses of this data set indicate that gene exchange occurred between populations of Chthamalus stellatus among the Atlantic islands, and between the eastern Atlantic population (Cork) and the western Mediterranean, while the eastern Mediterranean population was isolated from the other populations. This isolation may lead to a higher uniformity within population variation.

However, model analyses using AMOVA revealed a somewhat different pattern, namely, the separation of the Azores from the other Atlantic islands. The high variation within the population, resulting from the presence of many singleton haplotypes, may reflect mixing due to transport of genes across hydro- graphic barriers or may indicate the antiquity of the chthamalids, presenting the most plesiomorphic characters within the Balanomorpha, and the fast evolution of the CR.

The distribution and gene exchange between the different populations of Chthamalus stellatus may be explained by transport of larvae by oceanic currents, and the ability of this organism to cross hydrographic barriers. The current regime of the eastern Atlantic Ocean can explain the lack of significant genetic differences among the Atlantic Islands. The AzoresCanary current originates as a branch of the Gulf Stream around $40^{\circ} \mathrm{N}, 45^{\circ} \mathrm{W}$. In the summer, which is the main reproduction period of C. stellatus, it bifurcates; the northernmost band flows almost directly towards the Azores, while the other branch flows southeastward until it nears the African coast; on its way the current passes Madeira and the Canary Islands. Nevertheless, the exact path of the current varies seasonally and interannually (Klein \& Siedler 1989). The pattern of this current might explain the potential larval transfer between these islands, and the relative isolation of the Azores.

The isolation of the Azores population from the other Atlantic populations does not conform to results based on allozymes of GOT (Pannacciulli et al. 1997), which did not show significant population structure among the Atlantic populations, but separated the Atlantic and Mediterranean populations. Only the EF-1 $\alpha$ sequences of Chthamalus stellatus isolate the Atlantic population from the Mediterranean one (Shemesh et al. 2009), while those based on COI and ITS sequences (Shemesh et al. 2009) did not show significant population structure between Mediterranean and Atlantic populations. The isolation of the eastern Mediterranean population contradicts the previous analysis and ecological observations. The lack of differences between the populations of $C$. stellatus may be explained by the longevity and the ability of the larvae of C. stellatus to delay metamorphosis based on environmental conditions; these characteristics facilitate exchange of larvae between geographical areas (Crisp et al. 1981, Burrows 1999, Burrows et al. 1999) and may have allowed C. stellatus to maintain its widespread range, which includes offshore islands, and to overcome hydrographic barriers (O'Riordan et al. 2004, 2010). Recruitment of $C$. stellatus in Israel extends over the period of presence of fertilized egg masses in the mantle cavity of adults during the months of August and September, indicating the supply of new recruits from areas where reproduction does not coincide with that of the local population (T. Guy-Haim pers. comm.). This might be 
due to import of propagules from other areas. Pannacciulli \& Falautano (1999) found that in the years 1996 and 1997, C. stellatus larvae were released into the plankton from May to October, and those of $C$. montagui were released from March to September. Relini (1983) reported that around Genoa, Chthamalus species settle all year round with the exception of October and November, but Pannacciulli \& Relini (1999) reported different recruitment times in 1996 and 1997, when both species of Chthamalus settled only from June to December. These authors suggested that differences in timing could be related to interannual variations in reproduction and not to longevity and transport of larvae.

The isolation of the eastern Mediterranean can be explained by the circulation in the semi-enclosed Mediterranean Sea. The Mediterranean Sea contains evaporation basins connected to the North Atlantic Ocean through the narrow and relatively shallow Gibraltar Strait. Influx of relatively less saline water from the Atlantic, in the upper layers, flows through the Gibraltar Strait. Propagules from the Atlantic can be transferred by these less saline waters. In the Alboran Sea, the current forms an oceanographic front located from Almeria (Spain) to Oran (Algeria), called the Almeria-Oran Front, which restricts the dispersion of propagules and creates a genetic boundary for many marine organisms (for review, see Patarnello et al. 2007) including Chthamalus montagui, but not C. stellatus (Pannacciulli et al. 1997), which can cross this boundary. Burrows et al. (1999) suggested that the longer development time for larvae of C. stellatus compared to C. montagui has important consequences for the ecology and dispersal of the 2 species, limiting the crossing of the Almeria-Oran Front by the small larvae of C. montagui. The lack of significant differences in the CR sequences of $C$. stellatus between the population of Cork and that of St Jean Cap Ferrat, on both sides of the Almeria-Oran front, agrees with this model. From the Spanish coast, the flow of surface water to the east follows the North African coast (Algerian Current; Robinson et al. 1991). Further east, these waters flow into the eastern Mediterranean through the Siculo-Tunisian Strait, which may create another obstacle that limits the supply of new recruits. As the Atlantic water flows eastward in the summer, it is subjected to net evaporation, and thus the salinity increases. In the eastern Mediterranean, the Atlantic water appears as a subsurface flow at a depth of $50 \mathrm{~m}$, carrying with it potential recruits, since it is covered by the warm and saline Levantine Surface Water, which is formed by continual heating and evaporation. This current pattern may contribute to the isolation of the eastern Mediterranean population of C. stellatus.

\section{CONCLUSIONS}

Due to the limitations of the markers used, the results of the present study of our hypothesis that there is genetic variation among populations of Chthamalus stellatus needs further support. The low variability of the ND-2 gene within the chthamalids on the one hand, and the high variability of the CR within the different populations on the other hand, leaving only about $10 \%$ of the variation for identifying potential differences among populations, limit the validity of these genes for separation of populations of C. stellatus. Another pitfall of this study and other studies on the phylogeography of the Mediterranean Sea is the lack of material from the African coast, within the path of the oceanic currents from west to east. The phylogeographical study of chthamalids requires development of different sets of genetic markers which are 'intermediate' between the markers used in the present study, i.e. not a highly conserved one like ND-2, and on the other hand not so variable as the CR. It is possible that the use of microsatellites could fulfill these requirements and reveal significant differences among populations.

Acknowledgements. This study was supported by the US-Israel Binational Scientific Fund (BSF), grant 2004-239 and partly by the Israel Scientific Fund (ISF), grant 574/10. We thank A. Couto for samples from the Azores, D. Golani for samples from Tenerife, and R. M. O'Riordan for samples from Cork. We thank F. Pannacciulli from ENEA - Santa Teresa, E. Gefen from Tel Aviv University, and T. Guy-Haim from Bar Ilan University for comments and help in analysis.

\section{LITERATURE CITED}

Arif IA, Khan HA (2009) Molecular markers for biodiversity analysis of wildlife animals: a brief review. Anim Biodivers Conserv 32:9-17

> Brown JR, Beckenbach T, Smith MJ (1993) Intraspecific DNA sequence variation of the mitochondrial control region of white sturgeon (Acipenser transmontanus). Mol Biol Evol 10:326-341

> Burrows MT, Hawkins SJ, Southward AJ (1999) Larval development of the intertidal barnacles Chthamalus stellatus and C. montagui. J Mar Biol Assoc UK 79:93-101

Calderón I, Garrabou J, Aurelle D (2006) Evaluation of the utility of COI and ITS markers as tools for population genetic studies of temperate gorgonians. J Exp Mar Biol Ecol 336:184-197

Campo D, Molares J, Garcia L, Fernandez-Rueda P, GarciaGonzalez C, Garcia-Vazquez E (2009) Phlogeography of the European stalked barnacle (Pollicipes pollicipes): identification of glacial refugia. Mar Biol 157:147-156 
Castresana J (2000) Selection of conserved blocks from multiple alignments for their use in phylogenetic analysis. Mol Biol Evol 17:540-552

Chan BKK, Tsang LM, Ma KY, Hsu CH, Chu KH (2007) Taxonomic revision of the acorn barnacles Tetraclita japonica and Tetraclita formosana (Crustacea: Cirripedia) in East Asia based on molecular and morphological analyses. Bull Mar Sci 81:101-113

- Crisp DJ, Southward AJ, Southward EC (1981) On the distribution of the intertidal barnacles Chthamalus stellatus, Chthamalus montagui and Euraphia depressa. J Mar Biol Assoc UK 61:359-380

> Dando P, Southward AJ, Crisp DJ (1979) Enzyme variation in Chthamalus stellatus and C. momtagui (Crustacea: Cirripedia) evidence for the presence of C. montagui in the Adriatic. J Mar Biol Assoc UK 59:307-320

Excoffier L, Laval G, Schneider S (2005) ARLEQUIN version 3.0: an integrated software package for population genetics data analysis. Evol Bioinform Online 1:47-50

Fisher T, Katcoff DJ, Achituv Y (2004) Phylogenetic study of chthamaloids (Cirripedia; Thorcica; Chthamaloidae) based on 16S rDNA and COI sequence analysis. Biol J Linn Soc 83:39-45

> Katoh K, Kuma K, Toh H, Miyata T (2005) MAFFT version 5: improvement in accuracy of multiple sequence alignment. Nucleic Acids Res 33:511-518

Klein B, Siedler G (1989) On the origin of the Azores Current. J Geophys Res 94:6159-6168

Millot C, Taupier-Letage I (2005) Circulation in the Mediterranean Sea. Handb Environ Chem 5K:29-66

O'Riordan RM, Arenas F, Arrontes J, Castro JJ and others (2004) Spatial variation in the recruitment of the intertidal barnacles Chthamalus montagui Southward and Chthamalus stellatus (Poli) (Crustacea: Cirripedia) over an European scale. J Exp Mar Biol Ecol 304:243-264

O'Riordan RM, Power AM, Myers AA (2010) Factors at different scales affecting the distribution of species of the genus Chthamalus Ranzani (Cirripedia, Balanomorpha, Chthamaloidea). J Exp Mar Biol Ecol 392:46-64

Ochman H, Gerber AS, Hartl DL (1988) Genetic application of an inverse polymerase chain reaction. Genetics 120 : 621-623

> Owen CL, Messing CG, Rouse GW, Shivji MS (2009) Using a combined approach to explain the morphological and ecological diversity in Phanogenia gracilis Hartlaub, 1893 (Echinodermata: Crinoidea) sensu lato: two species or intraspecific variation Mar Biol 156:1517-1529

Pannacciulli FG, Falautano M (1999) Time of larval release in barnacles of the genera Chthamalus and Euraphia in the Gulf of Genoa (Ligurian Sea) and in the Gulf of Trieste (North Adriatic Sea)-Italy. Biol Mar Mediterr 6: 407-410

Pannacciulli FG, Relini G (1999) Time of settlement in barnacles of the genus Chthamalus in the Gulf of Genoa (Ligurian Sea) and in the Gulf of Trieste (North Adriatic Sea)-Italy. Biol Mar Mediterr 6:411-414

Pannacciulli FG, Bishop JDD, Hawkins SJ (1997) Genetic structure of populations of two species of Chthamalus (Crustacea: Cirripedia) in the north-east Atlantic and Mediterranean. Mar Biol 128:73-82

Patarnello T, Volckaert FAMJ, Castilho R (2007) Pillars of Hercules: Is the Atlantic-Mediterranean transition a phylogeographical break? Mol Ecol 16:4426-4444

Pie MR, Oliveira-Neto JF, Boeger WA, Ostrensky A, Baggio (2008) The organization of the mitochondrial control region in 2 brachyuran crustaceans: Ucides cordatus (Ocypodidae) and Cardisoma guanhumi (Gecarcinidae). J Hered 99:432-437
Puspasari IA, Yamaguchi T, Kojima S (2001) Phylogeny of the Balanus amphitrite complex occurring in Japan (Cirripedia: Balanidae) inferred from mitochondrial COI gene and morphology. Sessile Org 18:7-17

Relini G (1983) Remarks on the ecology of chthamalids in the Ligurian Sea. Rapp Comm Int Mer Mediterr 28:273-275

Robinson AR, Golnaraghi M, Leslie WG, Artegiani A and others (1991) The eastern Mediterranean general circulation: features, structure and variability. Dyn Atmos Oceans 15:215-240

Saiki RK, Gelfand DH, Stoffel S, Scharf SJ and others (1988) Primer-directed enzymatic amplification of DNA with a thermostable DNA polymerase. Science 239:487-491

Shadel GS, Clyton DA (1997) Mitochondrial DNA maintenance in vertebrates. Annu Rev Biochem 66:409-435

Shemesh E, Huchon D, Simon-Blecher N, Achituv Y (2009) The distribution and molecular diversity of the eastern Atlantic and Mediterranean chthamalids (Crustacea, Cirripedia). Zool Scr 38:365-378

Sorenson MD, Ast JC, Dimcheff DE, Yuri T, Mindell DP (1999) Primers for a PCR-based approach to mitochondrial genome sequencing in birds and other vertebrates. Mol Phylogenet Evol 12:105-114

Sotka EE, Wares JP, Barth JA, Grosberg RK, Palumbi SR (2004) Strong genetic clines and geographical variation in gene flow in the rocky intertidal barnacle Balanus glandula. Mol Ecol 13:2143-2156

> Sy A (1988) Investigation of large-scale circulation patterns in the central North Atlantic: the North Atlantic current, the Azores current, and the Mediterranean Water plume in the area of the Mid-Atlantic Ridge. Deep-Sea Res 35: $383-413$

Tajima F (1989) Statistical method for testing the neutral mutation hypothesis by DNA polymorphism. Genetics 123:585-595

Tsang LM, Chan BKK, Ma KY, Hsu CS, Chu KH (2007) Lack of mtDNA and morphological differentiation between two acorn barnacles Tetraclita japonica and T. formosana differing in parietes colours and geographical distribution. Mar Biol 151:147-155

> Tsang LM, Chan BKK, Wu TH, Ng WC, Chatterjee T, Williams GA, Chu KH (2008) Population differentiation in the barnacle Chthamalus malayensis: postglacial colonization and recent connectivity across the Pacific and Indian Oceans. Mar Ecol Prog Ser 364:107-118

van Syoc R (1994) Genetic divergence between subpopulations of the eastern Pacific goose barnacle Pollicipes elegans: mitochondrial cytochrome c oxidase subunit $1 \mathrm{nu}-$ cleotide sequences. Mol Mar Biol Biotechnol 3:338-346

van Syoc R (1995) Barnacle mitochondrial DNA: determining genetic relationships among species of Pollicipes. Crustac Issues 10:269-296

> Wares JP (2001) Patterns of speciation inferred from mitochondrial DNA in North American Chthamalus (Cirripedia: Balanomorpha: Chthamaloidea). Mol Phylogenet Evol 18:104-116

Williams JGK, Kubelik AR, Livak KJ, Rafalski JA, Tingey SV (1990) DNA polymorphisms amplified by arbitrary primers are useful as genetic markers. Nucleic Acids Res 18:6531-6535

Wilson AC, Cann RL, Carr SM, George M and others (1985) Mitochondrial DNA and two perspectives on evolutionary genetics. Biol J Linn Soc 26:375-400

York KL, Blacket MJ, Appleton BR (2008) The Bassian Isthmus and the major ocean currents of south-east Australia influence the phylogeography and population structure of a southern Australian intertidal barnacle, Catomerus polymerus (Darwin). Mol Ecol 17:1948-1961 
Appendix 1. Partial sequence of the mtDNA of Chthamalus stellatus: primer design and chromosome walking

Regular PCR and chromosome walking, using inverse PCR (IPCR) procedures, were employed to find the section of the mtDNA containing the proposed new markers, CR and ND2. This method is used to move systematically along a chromosome from a known location and to clone overlapping genomic clones. The CR and the ND-2 genes are flanked by the 12S rRNA and the COI. As a first step, we used the set of primers NR 1001 (sequences of primers are given in Table 1).

The forward primer was based on the 12S rRNA gene of Chthamalus stellatus (position 272 of the reverse complement of AJ242814). The reverse primer was based on the sequence of COI (position 255 of reverse complement of EU699253). Using these primers, a 453 bp segment was identified, composed of part of the ND-2 and tRNA-Trp.

From the alignment of the 4 known complete sequences of cirripede mtDNA, Megabalanus volcano (NC006293), Tetraclita japonica (NC008974), Policipes polymerus (NC005936; AY456188), and P. mitella (AY514042), we designed the degenerate forward primer of the set, NR1002; the reverse primer of this set is based on the tRNAtrp found in the previous step. Amplification using these primers revealed a $602 \mathrm{bp}$ fragment of the ND-2 gene.

For amplification of the $\mathrm{CR}$, we applied IPCR following the method described by Ochman et al. (1988). The first core region used was the sequence of 12S rRNA of Chthamalus stellatus (AJ242814). For the second IPCR, the core region was the ND-2 sequence identified by us in the first stage of the research. Since the size of the IPCR product was not known a priori, a relatively long extension stage was used; this can lead to non-specificity of the IPCR. Therefore, we performed 2 sequential IPCR reactions. The first reaction was performed with internal primers. The product of the first IPCR served as a template for a second specific IPCR reaction using nested primers, which gave the specific product.
For the IPCR based on the $12 \mathrm{~S}$ core, the EcoR1 restriction enzyme was used, the first set of primers was NR1003-out, and the nested primers were NR1003-nested. The product of this reaction included an elongation of the 12S rRNA gene in the upstream direction, a portion of the 16S rRNA, and the sequence of tRNA Val, which is flanked by these genes

The second IPCR reaction was based on the ND-2, isolated in the preceding step, using the restriction enzyme HindIII (its restriction site is found within the core region, downstream to the forward primer); the region of interest is found downstream to the reverse primer. The first set of primers used for amplification was NR1004out, the second set was NR1004nested. The products of these amplifications revealed 2 contigs, a $500 \mathrm{bp}$ long contig that includes tRNA Met and $433 \mathrm{bp}$ of ND-2; the second contig, $115 \mathrm{bp}$ in length, represents another portion of the ND-2 gene.

Additionally, we performed a third IPCR with primers based on the sequence of tRNA Met amplification; we used 2 restriction enzymes, NotI and BglIII, the set of primers was NR1006out, and 2 sets of nested primers, NR1006nestedA and NR1006nestedB. The restriction locus of NotI is unknown, but it is not within the core region. The restriction locus of BglIII is downstream of the forward primer, and the CR of interest is located downstream to the reverse primer. The product of this amplification is a $290 \mathrm{bp}$ long contig representing the CR.

Gaps between contigs revealed by the IPCR were closed using new primers based on the sequences detected in the preceding steps. The gap between AJ242814 (12S) and the CR was closed using the primer set 12SGap close. The gap between ND-2 and COI was closed by 2 sets of primers, YaCOIgap close and the 2 primers CStRW 26F and COI260R.

The sequences of the combined contigs, based on 2 specimens of Chthamalus stellatus from Dor, Israel, were deposited in GenBank under accession numbers JN989652 and JN998956.

Table A1. Chthamalus stellatus. Primers used for the construction of the mitochondrial DNA

\begin{tabular}{|c|c|c|}
\hline \multicolumn{3}{|l|}{ Primer } \\
\hline \multirow[t]{2}{*}{ NR 1001} & Forward & 5'-TTA CAG GGC AGG TTC CTC TAA ATG GGC-3' \\
\hline & Reverse & 5'-CCA GCT TCA ACA AGT GAA CCT C-3' \\
\hline \multirow{2}{*}{ NR 1002} & Forward & 5'-CAT TTC TGR TTT CCY SAA GT-3' \\
\hline & Reverse & 5'-GCT TTG AAG GCC ATC AG-3 \\
\hline \multirow[t]{2}{*}{ NR1003out } & Forward & 5'-AGC CCA TTT AGA GGA ACC TGC CC-3' \\
\hline & Reverse & 5'-CTA TCT TGC CGC CAA ATC CGC-3 \\
\hline \multirow[t]{2}{*}{ NR1003nested } & Forward & 5'-AGA GGT GGG TTA CAA TTT CAA GAG-3' \\
\hline & Reverse & 5'-TTG CCG CCA AAT CCG CTA AAT TTC-3' \\
\hline \multirow[t]{2}{*}{ NR 1004out } & Forward & 5'-TTC TTC CAT TTC YCA TTT GGG-3' \\
\hline & Reverse & 5'-AAC CTG ACA AAG CTC CTA CTA CAG C-3' \\
\hline \multirow[t]{2}{*}{ NR 1004nested } & Forward & 5'-TTY TAT CTT TAG GTG GTC TTC C-3' \\
\hline & Reverse & 5'-AAG GAG AGA TCT TCT GCC AAG TC-3' \\
\hline \multirow[t]{2}{*}{ NR1006out } & Forward & 5'-AGA TCC TTA ATC TTT TTT CTA TTT GGG GG-3' \\
\hline & Reverse & 5'-GCA GCC TCT CTT CTC TTT TTG TTG TTT TCC-3' \\
\hline \multirow{2}{*}{ NR1006nestedA } & Forward & 5'-TTG GCT TTG AGA ACT AAA TTG GGA ATG GC-3' \\
\hline & Reverse & 5'-ACT TCC AAT CCT ATT CAT ATT CC-3' \\
\hline \multirow[t]{2}{*}{ NR1006nestedB } & Forward & 5'-AAA GCG TGA GCC GTT ACA AT-3' ‘ \\
\hline & Reverse & 5'-ATC TCT CCT TTA GTG A-3 \\
\hline \multirow[t]{2}{*}{ 12Sgapclose } & Forward & 5'-GGG CAG GTT CCT CTA AAT GG-3' \\
\hline & Reverse & 5'-GAT CCA TGC AAA CAC ATA CTT AGA GTC-3' \\
\hline CStRW 26F & Forward & 5'-GCC TTC AAA GCC GTA ATT AG-3' \\
\hline CSCOI 260R & Reverse & 5'-CCC CAG CTT CAA CAA GTG A-3' \\
\hline \multirow[t]{2}{*}{ YaCOIgapclose } & Forward & 5'-GCA GTT TTA ATT GGC TCT AGT CTT G-3' \\
\hline & Reverse & 5'-AAA GCG TGA GCC GTT ACA AT-3' \\
\hline
\end{tabular}

